https:/ / doi.org/10.15407/mineraljournal.42.03.039

UDC 550.42 : 549.61 (477)

E.V. Levashova, PhD (Geology \& Mineralogy), Junior Research Fellow

Institute of Precambrian Geology and Geochronology of RAS

2, Makarova Emb., St. Petersburg, Russia, 199034

E-mail: levashova.kateryna@yandex.ru

https:/ / orcid.org/0000-0002-0814-1428

H.O. Kulchytska, DrSc (Geology), Chief Research Fellow

M.P. Semenenko Institute of Geochemistry, Mineralogy and Ore Formation (IGMOF) of NAS of Ukraine

34, Acad. Palladin Ave., Kyiv, Ukraine, 03142

E-mail: kulchechanna@gmail.com

https:/ / orcid.org/0000-0002-7206-4797

S.G. Skublov, DrSc (Geology \& Mineralogy), Prof., Chief Research Fellow

Institute of Precambrian Geology and Geochronology of RAS

2, Makarova Emb., St. Petersburg, Russia, 199034

Saint Petersburg Mining University

2, 21st Line, St. Petersburg, Russia, 199106

E-mail: skublov@yandex.ru

http:/ / orcid.org/0000-0002-5227-4260

I.M. Herasymets, PhD (Geology), Junior Research Fellow

M.P. Semenenko IGMOF of NAS of Ukraine

34, Acad. Palladin Ave., Kyiv, Ukraine, 03142

E-mail: Herasimets@i.ua

https:/ / orcid.org/0000-0003-4670-0216

S.G. Kryvdik, DrSc (Geology \& Mineralogy), Prof., Chief Research Fellow

M.P. Semenenko IGMOF of NAS of Ukraine 34, Acad. Palladin Ave., Kyiv, Ukraine, 03142

E-mail: kryvdik@ukr.net

https:/ / orcid.org/0000-0002-8356-1115

O.L. Galankina, PhD (Geology \& Mineralogy), Senior Research Fellow

Institute of Precambrian Geology and Geochronology of RAS

2, Makarova Emb., St. Petersburg, Russia, 199034

E-mail: galankinaol@mail.ru

Scopus ID: 7801578217

M.E. Mamykina, Student. Saint Petersburg Mining University 2, 21st Line, St. Petersburg, Russia, 199106

E-mail: emamikina@mail.ru

D.S. Levashov, PhD (Techn.), Associate prof. Saint Petersburg Mining University

2, 21st Line, St. Petersburg, Russia, 199106

E-mail: levashov_ds@pers.spmi.ru

https:/ / orcid.org/0000-0003-2776-5153

\title{
TRACE ELEMENT GEOCHEMISTRY OF ZIRCONS FROM THE VELYKA VYSKA SYENITE MASSIF, UKRAINIAN SHIELD
}

Zircon crystals from crushed syenite samples of individual intrusive bodies in the Velyka Vyska Massif were studied using the SEM-EDS (BSE images and chemistry) and SIMS methods. The results obtained were compared with early published data for zircon from the Azov and Yastrubets syenite massifs, Ukrainian Shield that host Zr-REE mineralization published earlier. Most of the zircon crystals analyzed are chemically inhomogeneous, but either azonal or show poorly-defined regular zoning. A darker

Cite: Levashova E.V., Kulchytska H.O., Skublov S.G., Herasymets I.M., Kryvdik S.G., Galankina O.L., Mamykina M.E., Levashov D.S. Trace Element Geochemistry of Zircons From the Velyka Vyska Syenite Massif, Ukrainian Shield. Mineral. Journ. (Ukraine). 2020. Vol. 42, No. 3. P. 39-49. https://doi.org/10.15407/mineraljournal.42.03.039 
contrasting marginal zone is visible only in scarce crystals. The presence of solid silicate, sulphide, phosphate and carbonate inclusions support the assumption that the zircon crystallization medium was heterogeneous. The percentages of rare-earth, radioactive and other trace elements are below $1.6 \mathrm{wt} . \%$ and their mean value of $0.4 \%$ is smaller than in zircon from other massifs. The percentage of $U+T h$ (average $0.07 \mathrm{wt} . \%$ ) is too small for radioactive elements to be responsible for metamictization. Similar to zircon from other massifs, $Y$, which predominates over REE at a ratio of $1.3: 1$, plays the leading role. As the total amounts of $Y$ and REE increase, REE composition becomes rich in LREE. Zircon from Velyka Vyska syenites has the highest HREE-content. The LREE/HREE mean ratio for this zircon is 0.06, while for Azov and Yastrubets zircons the ratio is 0.18 and 0.26, respectively. There are two types of REE distribution pattern for zircon crystals. Those of type I, characteristic of most crystals, are differentiated. They are identical to the pattern of central areas of crystals from other massifs and are typical of zircon which has crystallized from melt. Flattened spectra of type II are characteristic of crystal margins with a well-defined zonal structure. They are identical to those for the marginal parts of zircon crystals from other massifs and are characteristic of zircon crystallization in which a fluid phase was involved. The estimated zircon crystallization temperature calculated by Ti-thermometry is $600-1000^{\circ} \mathrm{C}$, commonly $700-800^{\circ} \mathrm{C}$, which is slightly lower than the values expected.

Keywords: zircon, syenite, Velyka Vyska massif, yttrium, radioactive and rare-earth elements, REE deposit.

Introduction. Zircon is a mineral occurring in practically all rock types. It plays a key role in solving many problems in mineralogy, geochemistry, geochronology and other fields of geology. Zircon is one of the best-studied minerals. However, the development of more sophisticated analytical methods opens up new prospects in the study of zircon. In spite of the relatively constant chemical composition of the mineral, it contains the impurities of rare-earth and many other trace elements. The trace element composition of zircon, together with the study of its internal structure, may cast light on the conditions of its formation. It is also widely used for reconstructing the conditions of formation of its igneous and metamorphic host rocks by analyzing the evolution pattern of melts and a fluid regime upon zircon crystallization.

Study area. There are syenite massifs of Proterozoic age with high-grade zircon deposits in the Ukrainian Shield (US). The best-known massifs are Yastrubets (Volyn Megablock), Azov and Octiabrsky (Priazov Megablock) [5]. The massifs display $\mathrm{Zr}$ and $R E E+\mathrm{Y}$ mineralization. The Octiabrsky massif also exhibits $\mathrm{Nb}$-mineralization [4].

In contrast to the Octiabrsky massif, in which syenites are typically alkaline [7], Yastrubets and Azov nepheline-free syenites are sub-alkaline rocks locally enriched in quartz. They are remarkable for the high iron content of femic minerals and the prevalence of alkaline monofeldspar of K-Nacomposition (anorthoclase), which now occurs as perthitic albite ingrowths in orthoclase or microcline matrix. The formation of anorthoclase indicates that the rock has crystallized under hypersolvus conditions, hence the name hypersolvus given to the syenites $[16,17]$. They are also known as nepheline-free, monofeldspathic and rare-metal syenites [6,10]. Zircon from these massifs is unique not only due to its quantity in ore-hosting rocks and crystal size but also to its trace and rare-earth element concentrations [15]. REE concentration in zircon is sometimes anomalously high (up to 4 wt.\% REE and up to $8 \mathrm{wt} . \%$ Y from the Yastrubets ore occurrence).

Two more syenite massifs of this type known in the Ukrainian Shield are Velyka Vyska (Ingul Megablock) and Davydky (Volyn Megablock). Zircon mineralization in the latter is represented by baddeleyite. Zircon also occurs in small amounts in baddeleyite-bearing rocks (syenites and gabbroic rocks) from this massif.

The Velyka Vyska massif is a tentative name for individual, often linear, bodies intersected by boring on the southern margin of the Korsun-Novomyrgorod Pluton, US. These small (the biggest intrusions are up to $2 \mathrm{~km}$ long) syenite intrusions commonly occur among Korsun-Novomyrgorod granites. Dike-like fayalitic syenite bodies are also encountered outside the above pluton among older (ca. $2.0 \mathrm{Ga}$ ) biotite-garnet granites occurring in the Novoukrainian Massif. The composition of the rocks intersected varies from monzonite to leucocratic syenite, but fayalitic-hedenbergitic (with ferrohastingsite) medium- to fine-grained syenites predominate. Ilmenite- and zircon-enriched melanocratic (up to $35 \%$ dark-coloured minerals) varieties are occasionally encountered [6, 8]. Anorthoclase-microperthite, sanidine-microperthite, fayalite, hedenbergite, ferrohastingsite, ilmenite and quartz (5-10\%) are rock-forming minerals in Velyka Vyska rocks. Zircon, apatite, chevkinite, allanite, britholite and lesser fluorite and bastnasite occur as accessories. Zircon is present in all rock types from the Velyka Vyska massif. It is closely associated with apatite and $R E E$-minerals and, together with them, is confined to femic mineral aggregates [2]. Some of zircon crystals are up to $3 \mathrm{~mm}$ long, but no large-scale zircon or REE-mineral 
Fig. 1. Zircon crystals from Velyka Vyska syenites. Image in a BSE regime. The ion probe crater diameter is $\approx 20 \mu \mathrm{m}$. Point numbers are consistent with numbers in Table
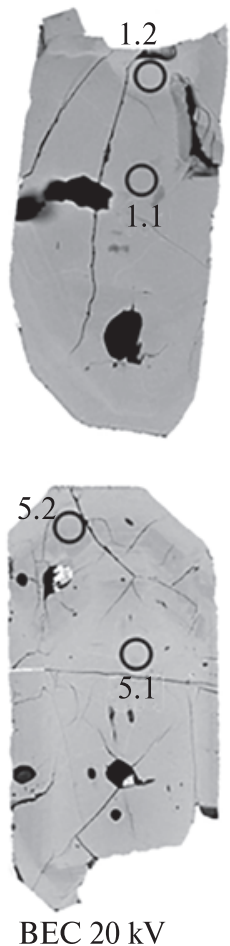

BEC $20 \mathrm{kV}$
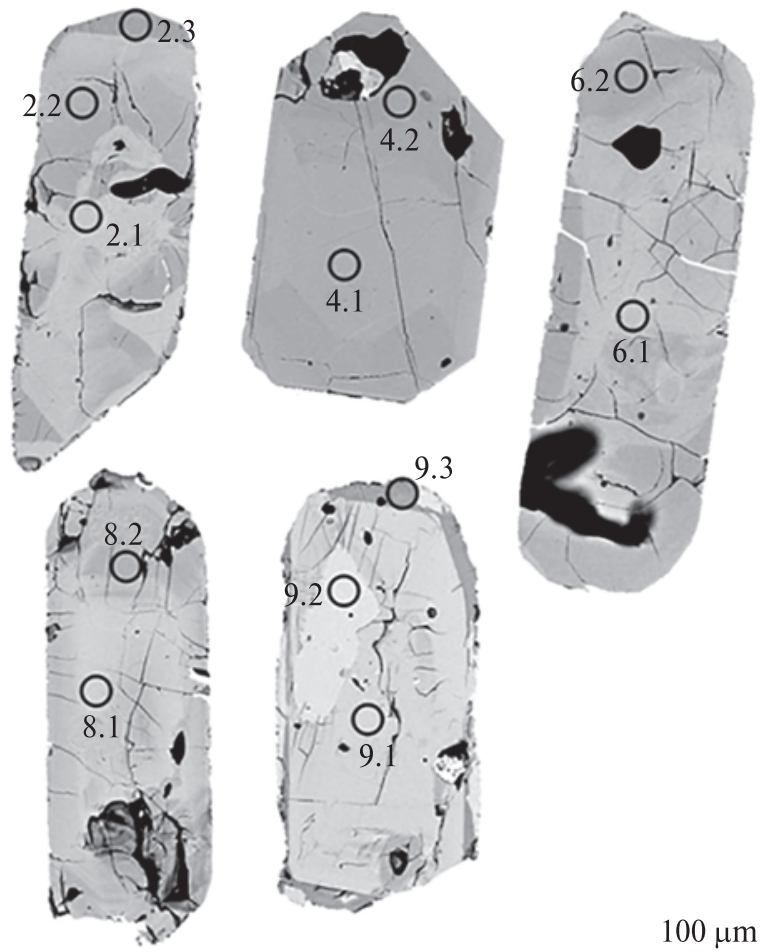

$100 \mu \mathrm{m}$ aggregates in the massif have been located a feature used to distinguish between the Velyka Vyska and Azov and Yastrubets massifs. Velyka Vyska syenites have much in common with Azov and Yastrubets syenites, except for the aforementioned characteristics. The massifs are similar in chemical and mineral composition and the compositions of accessory minerals and ore constituents. Azov syenites are most similar to them.

The goal of the present study is to analyze the trace element composition of zircon from the Velyka Vyska massif and to compare it with that of zircon from the Azov and Yastrubets massifs. This will make it possible to assess the differentiation of the Velyka Vyska massif in more detail and to support and update earlier conclusions of the heterogeneity of the zircon crystallization medium [12] .

Methods. The chemical major element composition and internal structure of zircon were analyzed. The presence of mineral phase inclusions in zircon was checked and their composition was analyzed on a JEOL JSM-6510LA scanning electron microscope with an (EDS) JED-2200 energy dispersion spectrometer in a back-scattered electron (BSE) regime (IPGG RAS). REE and trace element concentrations in zircon were estimated using the secondary ion mass-spectrometry method (SIMS) on a Cameca IMS-4f ion microprobe (Valiev IPT RAS, Yaroslavl Branch) and standard techniques [19, 21]. Zircon crystallization temper- ature was calculated with a "Ti-in-zircon" thermometer [24]. When constructing REE distribution spectra, zircon composition was normalized to chondrite CI composition [23].

Results. Ten zircon crystals, 0.2 to $0.7 \mathrm{~mm}$ in size, from ten $2-3 \mathrm{~kg}$ crushed ore-bearing syenite core samples from 7 boreholes that intersected individual bodies in the Velyka Vyska massif were studied. The crystals display a dipyramidal-prismatic habit (Fig. 1). Crystals of isometric habit with a complex external facet configuration are occasionally encountered. Most crystals are opaque and have a yellow or brown colour.

Their heterogenous structure, formed by alternation of parts with various shades of grey, is well defined on a BSE image. The zircons analyzed generally have a light grey central part and a darker margin. A well defined zonal structure is displayed by scarce crystals with very dark margins. The zones are either mottled or display an alternation of light and dark zones. Crystal colour intensity on a BSE image varies near solid-phase inclusions: the colour becomes lighter around some of them and gets darker near others (Fig. 1). Fracturing in the zircon samples is ubiquitous; it is best-developed near some of the inclusions and in the marginal part.

Solid-phase inclusions in zircon. It is known [11, 12] that zircon crystals from the Velyka Vyska massif contain a great variety of mineral microinclusions. Most of them are the accessory minerals of 
The content of trace elements in zircon from Velyka Vyska syenite massif, ppm

\begin{tabular}{|c|c|c|c|c|c|c|c|c|c|c|c|c|c|}
\hline \multirow{4}{*}{ Component } & \multicolumn{13}{|c|}{ Sample, point of analysis } \\
\hline & 1.1 & 1.2 & 2.1 & 2.2 & 2.3 & 3.1 & 3.2 & 4.1 & 4.2 & 5.1 & 5.2 & 6.1 & 6.2 \\
\hline & \multicolumn{2}{|c|}{ 200/858 BH } & \multicolumn{3}{|c|}{ 203/840 BH } & \multicolumn{2}{|c|}{ 205/840 BH } & \multicolumn{2}{|c|}{$225 / 809 \mathrm{BH}$} & \multicolumn{2}{|c|}{ 236/859 BH } & \multicolumn{2}{|c|}{ 241/859 BH } \\
\hline & $\begin{array}{c}\text { dark } \\
\text { center }\end{array}$ & $\begin{array}{l}\text { light } \\
\text { edge }\end{array}$ & $\begin{array}{l}\text { light } \\
\text { center }\end{array}$ & $\begin{array}{c}\text { dark } \\
\text { center }\end{array}$ & $\begin{array}{l}\text { dark } \\
\text { zone }\end{array}$ & $\begin{array}{l}\text { light } \\
\text { center }\end{array}$ & $\begin{array}{l}\text { dark } \\
\text { edge }\end{array}$ & $\begin{array}{l}\text { light } \\
\text { center }\end{array}$ & $\begin{array}{l}\text { dark } \\
\text { edge }\end{array}$ & $\begin{array}{l}\text { light } \\
\text { center }\end{array}$ & $\begin{array}{l}\text { dark } \\
\text { edge }\end{array}$ & $\begin{array}{l}\text { light } \\
\text { center }\end{array}$ & $\begin{array}{l}\text { dark } \\
\text { edge }\end{array}$ \\
\hline $\mathrm{La}$ & 0.09 & 0.31 & 0.19 & 0.11 & 0.04 & 0.24 & 0.03 & 0.10 & 0.02 & 0.43 & 0.08 & 6.25 & 0.20 \\
\hline $\mathrm{Ce}$ & 10.2 & 9.91 & 6.38 & 10.1 & 2.87 & 25.2 & 11.1 & 10.1 & 7.28 & 23.4 & 13.5 & 53.1 & 12.2 \\
\hline $\operatorname{Pr}$ & 0.15 & 0.17 & 0.18 & 0.15 & 0.04 & 0.98 & 0.11 & 0.96 & 0.09 & 1.24 & 0.13 & 3.63 & 0.35 \\
\hline $\mathrm{Nd}$ & 2.55 & 0.76 & 2.04 & 1.42 & 0.71 & 14.3 & 1.93 & 15.6 & 1.25 & 19.0 & 1.61 & 30.2 & 2.60 \\
\hline $\mathrm{Sm}$ & 5.15 & 0.77 & 2.71 & 2.02 & 1.35 & 22.6 & 3.92 & 19.3 & 2.75 & 27.0 & 2.83 & 29.0 & 3.66 \\
\hline $\mathrm{Eu}$ & 0.22 & 0.02 & 0.40 & 0.26 & 0.12 & 0.44 & 0.15 & 0.95 & 0.12 & 0.59 & 0.07 & 1.20 & 0.21 \\
\hline $\mathrm{Gd}$ & 26.4 & 4.70 & 13.3 & 10.2 & 6.09 & 111 & 17.2 & 70.9 & 14.0 & 124 & 13.6 & 99.2 & 15.7 \\
\hline Dy & 82.5 & 21.0 & 50.8 & 38.2 & 20.6 & 378 & 52.0 & 192 & 51.9 & 360 & 51.0 & 305 & 49.6 \\
\hline $\mathrm{Er}$ & 144 & 54.4 & 156 & 76.9 & 38.0 & 627 & 94.3 & 302 & 95.5 & 554 & 97.7 & 475 & 82.7 \\
\hline $\mathrm{Yb}$ & 234 & 118 & 391 & 131 & 69.0 & 870 & 153 & 427 & 161 & 773 & 155 & 700 & 145 \\
\hline $\mathrm{Lu}$ & 37.6 & 17.6 & 70.8 & 21.0 & 11.7 & 129 & 24.7 & 66.3 & 25.1 & 123 & 25.3 & 108 & 23.4 \\
\hline $\mathrm{Li}$ & 0.14 & 1.00 & 0.45 & 0.05 & 0.07 & 0.74 & 0.32 & 0.40 & 0.28 & 0.88 & 0.42 & 0.73 & 0.29 \\
\hline $\mathrm{P}$ & 67.0 & 130 & 46.9 & 75.2 & 49.0 & 101 & 100 & 81.4 & 26.3 & 129 & 54.1 & 86.4 & 311 \\
\hline $\mathrm{Ca}$ & 24.9 & 316 & 35.7 & 115 & 43.5 & 37.4 & 20.3 & 24.6 & 21.5 & 59.0 & 1396 & 58.0 & 238 \\
\hline $\mathrm{Ti}$ & 15.9 & 4.74 & 28.6 & 12.0 & 29.0 & 7.56 & 15.3 & 17.3 & 17.1 & 9.67 & 7.73 & 14.1 & 16.7 \\
\hline $\mathrm{Sr}$ & 0.70 & 1.80 & 0.69 & 1.12 & 0.51 & 0.91 & 0.85 & 0.88 & 0.48 & 2.10 & 2.79 & 1.49 & 0.89 \\
\hline $\mathrm{Y}$ & 746 & 254 & 650 & 402 & 202 & 3531 & 506 & 1676 & 560 & 3261 & 524 & 2672 & 499 \\
\hline $\mathrm{Nb}$ & 66.4 & 32.2 & 46.8 & 37.0 & 35.5 & 42.3 & 32.2 & 19.4 & 31.3 & 39.6 & 33.1 & 94.6 & 51.6 \\
\hline $\mathrm{Ba}$ & 1.65 & 10.2 & 3.64 & 1.17 & 1.76 & 2.46 & 3.36 & 7.48 & 1.53 & 4.43 & 1.68 & 32.7 & 10.0 \\
\hline $\mathrm{Hf}$ & 11407 & 13379 & 12257 & 11924 & 10519 & 12250 & 10597 & 10165 & 11127 & 10614 & 11873 & 12483 & 9956 \\
\hline Th & 82.8 & 74.7 & 114 & 59.1 & 17.7 & 419 & 82.3 & 118 & 52.5 & 381 & 76.0 & 409 & 63.0 \\
\hline $\mathrm{U}$ & 125 & 345 & 672 & 146 & 57.1 & 634 & 133 & 153 & 97.4 & 449 & 153 & 486 & 114 \\
\hline $\mathrm{Th} / \mathrm{U}$ & 0.66 & 0.22 & 0.17 & 0.41 & 0.31 & 0.66 & 0.62 & 0.77 & 0.54 & 0.85 & 0.50 & 0.84 & 0.55 \\
\hline $\mathrm{Eu} / \mathrm{Eu}^{*}$ & 0.06 & 0.03 & 0.20 & 0.17 & 0.13 & 0.03 & 0.06 & 0.08 & 0.06 & 0.03 & 0.03 & 0.07 & 0.08 \\
\hline $\mathrm{Ce} / \mathrm{Ce}^{*}$ & 21.3 & 10.4 & 8.28 & 19.0 & 16.2 & 12.6 & 49.3 & 7.81 & 43.4 & 7.81 & 30.7 & 2.70 & 11.2 \\
\hline$\Sigma R E E$ & 542 & 228 & 693 & 291 & 151 & 2179 & 359 & 1105 & 359 & 2006 & 361 & 1811 & 336 \\
\hline$\Sigma L R E E$ & 13.0 & 11.2 & 8.79 & 11.7 & 3.67 & 40.7 & 13.2 & 26.7 & 8.64 & 44.1 & 15.3 & 93.2 & 15.4 \\
\hline$\Sigma H R E E$ & 524 & 216 & 681 & 277 & 145 & 2115 & 342 & 1058 & 347 & 1934 & 343 & 1688 & 317 \\
\hline $\mathrm{Lu}_{N} / \mathrm{La}_{N}$ & 3953 & 543 & 3529 & 1851 & 2708 & 5242 & 8428 & 6290 & 12911 & 2788 & 2898 & 167 & 1134 \\
\hline $\mathrm{Lu}_{N} / \mathrm{Gd}_{N}$ & 11.5 & 30.3 & 43.1 & 16.6 & 15.5 & 9.44 & 11.6 & 7.56 & 14.5 & 8.05 & 15.0 & 8.83 & 12.1 \\
\hline $\mathrm{Sm}_{N} / \mathrm{La}_{N}$ & 90.1 & 3.97 & 22.5 & 29.5 & 52.1 & 152 & 223 & 304 & 235 & 102 & 53.9 & 7.42 & 29.5 \\
\hline$T(\mathrm{Ti}),{ }^{\circ} \mathrm{C}$ & 786 & 681 & 845 & 759 & 847 & 719 & 782 & 794 & 792 & 740 & 721 & 775 & 790 \\
\hline
\end{tabular}

trace and rare-earth elements. Rock-forming mineral inclusions and unidentifiable solid phases of $\mathrm{Al}-\mathrm{Fe}$-silicate composition are also widespread.

The rock-forming minerals of syenites such as albite, K-feldspar, quartz and to lesser extent hedenbergite, annite and hastingsite that occur as inclusions in the zircon crystal samples were diagnosed by the SEM-EDS method.

Most of the inclusions are in the central zone of the zircon crystals and occur as individual mine- rals and rock-forming minerals intergrowths, e.g. albite + K-feldspar, quartz + albite, and also form a common inclusion with an $\mathrm{Al}-\mathrm{Fe}$-silicate phase. The relationship between the amorphous phase and mineral inclusions is illustratedin $[11,12]$. It should be noted that the Al-Fe-silicate phase has a complex, variable composition $(\mathrm{FeO}-34-78$, $\mathrm{SiO}_{2}-7-36, \mathrm{Al}_{2} \mathrm{O}_{3}-4-19, \mathrm{~K}_{2} \mathrm{O}$ and $\mathrm{CaO}-$ 1-3 wt.\%) and, therefore, cannot be diagnosted mineralogically. The variable composition of con-

ISSN 2519-2396. Mineral. Journ. (Ukraine). 2020. 42, No. 3 


\begin{tabular}{|c|c|c|c|c|c|c|c|c|}
\hline \multicolumn{9}{|c|}{ Sample, point of analysis } \\
\hline 7.1 & 7.2 & 8.1 & 8.2 & 9.1 & 9.2 & 9.3 & 10.1 & 10.2 \\
\hline \multicolumn{2}{|c|}{$168 / 860 \mathrm{BH}$} & \multicolumn{2}{|c|}{$172 / 860 \mathrm{BH}$} & \multicolumn{3}{|c|}{$178 / 865 \mathrm{BH}$} & \multicolumn{2}{|c|}{$192 / 858 \mathrm{BH}$} \\
\hline $\begin{array}{l}\text { light } \\
\text { center }\end{array}$ & $\begin{array}{l}\text { dark } \\
\text { edge }\end{array}$ & $\begin{array}{l}\text { light } \\
\text { center }\end{array}$ & $\begin{array}{l}\text { dark } \\
\text { zone }\end{array}$ & $\begin{array}{c}\text { light } \\
\text { center }\end{array}$ & $\begin{array}{c}\text { light } \\
\text { area } \\
\text { in center }\end{array}$ & $\begin{array}{l}\text { dark } \\
\text { zone }\end{array}$ & $\begin{array}{l}\text { light } \\
\text { center }\end{array}$ & $\begin{array}{l}\text { dark } \\
\text { edge }\end{array}$ \\
\hline 0.49 & 4.99 & 16.1 & 6.16 & 44.3 & 0.02 & 58.9 & 0.20 & 0.11 \\
\hline 133 & 56.1 & 123 & 24.2 & 103 & 3.42 & 134 & 9.43 & 7.34 \\
\hline 6.11 & 3.85 & 8.14 & 2.47 & 7.51 & 0.02 & 16.2 & 0.97 & 0.13 \\
\hline 100 & 38.3 & 95.6 & 12.8 & 26.4 & 0.13 & 58.7 & 13.8 & 2.15 \\
\hline 122 & 36.5 & 97.9 & 4.32 & 16.7 & 0.43 & 27.2 & 23.5 & 4.40 \\
\hline 2.57 & 0.89 & 2.35 & 0.32 & 0.32 & 0.02 & 1.57 & 1.33 & 0.14 \\
\hline 408 & 126 & 298 & 8.62 & 79.6 & 5.48 & 57.6 & 95.9 & 19.2 \\
\hline 1043 & 322 & 677 & 29.9 & 258 & 50.0 & 319 & 263 & 61.7 \\
\hline 1354 & 468 & 925 & 57.5 & 461 & 202 & 821 & 390 & 109 \\
\hline 1778 & 634 & 1230 & 92.0 & 669 & 624 & 1714 & 566 & 171 \\
\hline 253 & 88.8 & 186 & 14.2 & 96.8 & 111 & 250 & 86.6 & 26.8 \\
\hline 12.5 & 0.72 & 3.92 & 0.44 & 0.59 & 1.49 & 3.57 & 0.33 & 0.18 \\
\hline 145 & 291 & 112 & 82.2 & 123 & 118 & 231 & 41.2 & 82.4 \\
\hline 27.2 & 234 & 58.2 & 193 & 77.9 & 36.2 & 7970 & 19.4 & 32.3 \\
\hline 11.9 & 16.6 & 11.6 & 9.61 & 7.30 & 0.77 & 11.5 & 15.1 & 11.0 \\
\hline 1.55 & 3.07 & 1.78 & 2.73 & 1.75 & 2.14 & 167 & 1.00 & 0.49 \\
\hline 8381 & 2348 & 5380 & 335 & 2543 & 873 & 4075 & 2267 & 600 \\
\hline 104 & 59.9 & 44.5 & 30.0 & 109 & 118 & 192 & 29.0 & 25.3 \\
\hline 2.34 & 147 & 11.3 & 292 & 9.55 & 4.16 & 194 & 2.47 & 3.12 \\
\hline 7874 & 11236 & 8318 & 9976 & 12121 & 29440 & 21802 & 8136 & 8973 \\
\hline 1113 & 272 & 713 & 32.9 & 436 & 63.3 & 570 & 133 & 34.1 \\
\hline 741 & 284 & 467 & 90.7 & 756 & 2365 & 4332 & 167 & 65.1 \\
\hline 1.50 & 0.96 & 1.53 & 0.36 & 0.58 & 0.03 & 0.13 & 0.80 & 0.52 \\
\hline 0.04 & 0.04 & 0.04 & 0.16 & 0.03 & 0.03 & 0.12 & 0.09 & 0.05 \\
\hline 18.6 & 3.10 & 2.59 & 1.50 & 1.37 & 45.8 & 1.05 & 5.17 & 15.0 \\
\hline 5200 & 1780 & 3659 & 253 & 1763 & 997 & 3459 & 1451 & 402 \\
\hline 240 & 103 & 242 & 45.6 & 181 & 3.59 & 267 & 24.4 & 9.73 \\
\hline 4836 & 1639 & 3317 & 202 & 1564 & 993 & 3162 & 1401 & 387 \\
\hline 4923 & 172 & 111 & 22.2 & 21.1 & 58905 & 40.9 & 4154 & 2393 \\
\hline 5.01 & 5.70 & 5.05 & 13.3 & 9.84 & 164 & 35.1 & 7.31 & 11.3 \\
\hline 393 & 11.7 & 9.74 & 1.12 & 0.61 & 37.5 & 0.74 & 187 & 65.3 \\
\hline 758 & 790 & 757 & 739 & 716 & 558 & 755 & 781 & 751 \\
\hline
\end{tabular}

stituents is more typical of amorphous substances such as silicate glass. Therefore, an Al-Fe-silicate phase is interpreted as having been produced by crystallization of conserved magmatic melt [12]. Trace and rare-earth minerals, such as thorite, baddeleyite, parisite, bastnasite, allanite and fluorapatite with 5-21 wt.\% $R E E_{2} \mathrm{O}_{3}$, occur as inclusions. These minerals always form polymineral inclusions that also comprise chalcopyrite (lesser sphalerite) and an Al-Fe-silicate phase. Such polymineral in- clusions occurring on zircon crystal margins are also regarded here as having been produced by crystallization of conserved magmatic melt [12]. The varied composition of inclusions formed by crystallization of conserved magmatic melts is indicative of medium heterogenization caused presumably by immiscibility in magma, particularly the subdivision of silicate melt into leucocratic and melanocratic and the separation of trace elementenriched salt (sulphide, phosphate and carbonate) melt from silicate melt [13].

The presence of baddeleyite in the zircon samples is noteworthy. Baddeleyite inclusions are worth discussing in a separate publication, because they are seldom found due to a difference in the crystallization conditions of two $\mathrm{Zr}$-minerals.

Rare-earth composition of zircon. Electron microprobe (SEM-EDS) study has shown that most of the zircon samples contain small amounts of impurities; only hafnium (no more than 3 wt.\% $\mathrm{HfO}_{2}$ ) is often observed, and traces of $\mathrm{Al}_{2} \mathrm{O}_{3}$ (less than 1 wt. are encountered. $\mathrm{FeO}(2-3$ wt. \%), $\mathrm{MnO}$ (1), $\mathrm{CaO}(2), \mathrm{Na}_{2} \mathrm{O}(<1)$ impurities are seen only in the dark-grey areas of zircon on the BSE image.

Trace and rare-earth element concentrations were calculated by the SIMS method at 22 points in 10 zircon crystals (Table). The irregular distribution of impurity elements, which has resulted in the heterogenous structure of crystals on the BSE image, is noteworthy. $\mathrm{Y}$ and $R E E$ concentrations have changed tenfold, those of $\mathrm{P}$ and $\mathrm{Nb}$ by one order of magnitude and $\mathrm{Ca}$, Th, U, Ti by two orders of magnitude.

Two types of $R E E$ distribution spectra in zircon are characteristic. For most of the crystals, the $R E E$ distribution patterns in the centre and on the margins of zircon display a kind of trend within one order of chondrite relations (Fig. 2). They commonly exhibit a differentiated light to heavy $R E E$ distribution spectrum (mean $\mathrm{Lu}_{\mathrm{N}} / \mathrm{La}_{\mathrm{N}}$ ratio is $3462)$ with a distinct positive $\mathrm{Ce}$-anomaly $\left(\mathrm{Ce} / \mathrm{Ce}^{*}\right.$ from 2.70 to 49.3, average 15.8), a negative $\mathrm{Eu}-$ anomaly ( $\mathrm{Eu} / \mathrm{Eu}^{*}$ from 0.03 to 0.20 , mean value $0.07)$ and relatively low total $R E E$ concentration (200-5200 ppm), which depends mainly on HREE contribution.

However, there is a difference between the central and marginal areas of azonal crystals. The central parts of zircon crystals that are light grey on BSE images differ from slightly darker marginal zones in a markedly smaller Ce-anomaly value, although the Eu-anomaly value and higher $R E E$ concentration remain unchanged. The total REE 


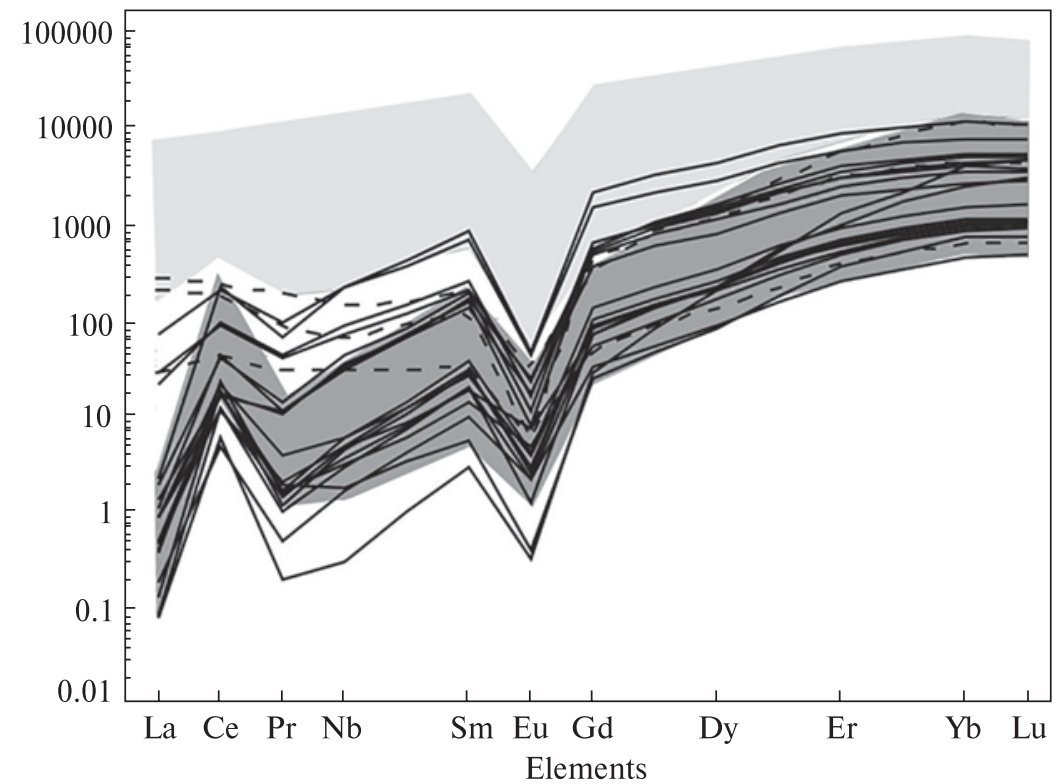

Fig. 2. REE distribution spectra in zircon. The solid line is for the central and marginal parts of most zircon crystals from Velyka Vyska syenites; the dotted line is for the dark marginal parts of scarce zircon crystals from Velyka Vyska syenites. Dark grey filling which indicates the $R E E$ distribution spectrum range is for the central parts of the zircon from Azov and Yastrubets syenites and light grey filling is for the marginal parts of zircon from Azov and Yastrubets syenites. REE concentration is normalized to chondrite CI [23] concentration in the centre of the crystals is 400$5200 \mathrm{ppm}$ against $200-2000 \mathrm{ppm}$ in the marginal parts. The concentrations of other non-formula elements are generally higher in the central area of zircon but do not exceed the threshold values accepted [20], persisting in the range characteristic of igneous zircon. For example, $Y$ concentration in the central area varies from 110 to $8400 \mathrm{ppm}$, showing a strong positive correlation with $H R E E$. $\mathrm{Nb}$ concentration varies from 20 to $100 \mathrm{ppm}, \mathrm{P}-25-$ $255 \mathrm{ppm}$. The concentrations of zircon-incompatible elements such as $\mathrm{Sr}, \mathrm{Li}$ and $\mathrm{Ba}$ are small, commonly varying within a few ppm. Ion mass-spectrometry has confirmed small radioactive element concentrations in zircon known earlier from the results of microprobe calculations [2]. Average Th and $U$ concentrations are 277 and $352 \mathrm{ppm}$, respectively; $\mathrm{Th} / \mathrm{U}$ ratio varies from 0.17 to 1.50 (mean value 0.73 ). It should be noted that only $\mathrm{Ca}$ and $\mathrm{Ti}$ did not tend to decrease their concentrations from the centre of a crystal to its margin. For example, Ca concentration in the central zone is $59 \mathrm{ppm}$ and that in the marginal zone is $220 \mathrm{ppm}$, whole Ti concentrations are 25 and $56 \mathrm{ppm}$, respectively. Hf distribution within a crystal remains practically unchanged, averaging $10900 \mathrm{ppm}$, and only scarce crystals exhibit either a marked increase (up to $29000 \mathrm{ppm}$ ) or a decline (to $8100 \mathrm{ppm}$ ) in Hf concentration. The above compositional characteristics are consistent with those of igneous zircon [22].

Different $R E E$ distribution spectra were obtained for zonal zircon crystals with a well defined marginal zone, much darker than the one on the BSE image (samples 8 and 9). They generally display
$R E E$ patterns not typical of zircon, e.g. flattened spectra characteristic of zircon from intensive fluid reworking zones [18]. In this case, Ce-anomaly disappears $\left(\mathrm{Ce} / \mathrm{Ce}^{*}=1.05-1.50\right)$, the Eu-anomaly value remains almost the same or even increases slightly. The differentiation index of the REE spectra $\left(\mathrm{Lu}_{\mathrm{N}} / \mathrm{La}_{\mathrm{N}}\right)$ is only $21-41$ (Table), whereas the light central zone of this zircon typically displays a differentiated REE pattern similar to spectra for most zircon crystals from the Velyka Vyska massif and consistent with typical zircon of magmatic genesis (Fig. 2). Impurity concentrations in the dark marginal zones of zircon commonly increase. $\mathrm{Ca}, \mathrm{Ba}, \mathrm{Th}, \mathrm{U}, \mathrm{Y}$ and $R E E$ concentrations display the greatest increase. For example, $\mathrm{Ca}$ concentration in the darkest marginal zones increases 200 times (sample 9) in comparison with the central zones of zircon (8000 against $36 \mathrm{ppm}$ ), $\mathrm{Y}-4.5$ times; $R E E-3.5$ times and $\mathrm{Th}$ and $\mathrm{U}-$ $6-10$ times. In this case, the $\mathrm{Th} / \mathrm{U}$ ratio in such zones is as small as $0.03-0.56$. Other impurity element concentrations vary slightly or even decrease from the centre to the periphery of the crystal (Table).

Approximate zircon crystallization temperature was calculated from the results of the Ti-Zr equilibrium in zircon using the method described in [24]. A value in excess of $1000{ }^{\circ} \mathrm{C}$ was obtained in one case, but it varies generally from 600 to $800{ }^{\circ} \mathrm{C}$ for all crystal parts, which is not consistent with the results of fluid thermometry [11] and the mineral paragenesis observed. This problem exists for zircon from Azov syenites [14], but this subject is beyond the scope of this paper.

ISSN 2519-2396. Mineral. Journ. (Ukraine). 2020. 42, No. 3 


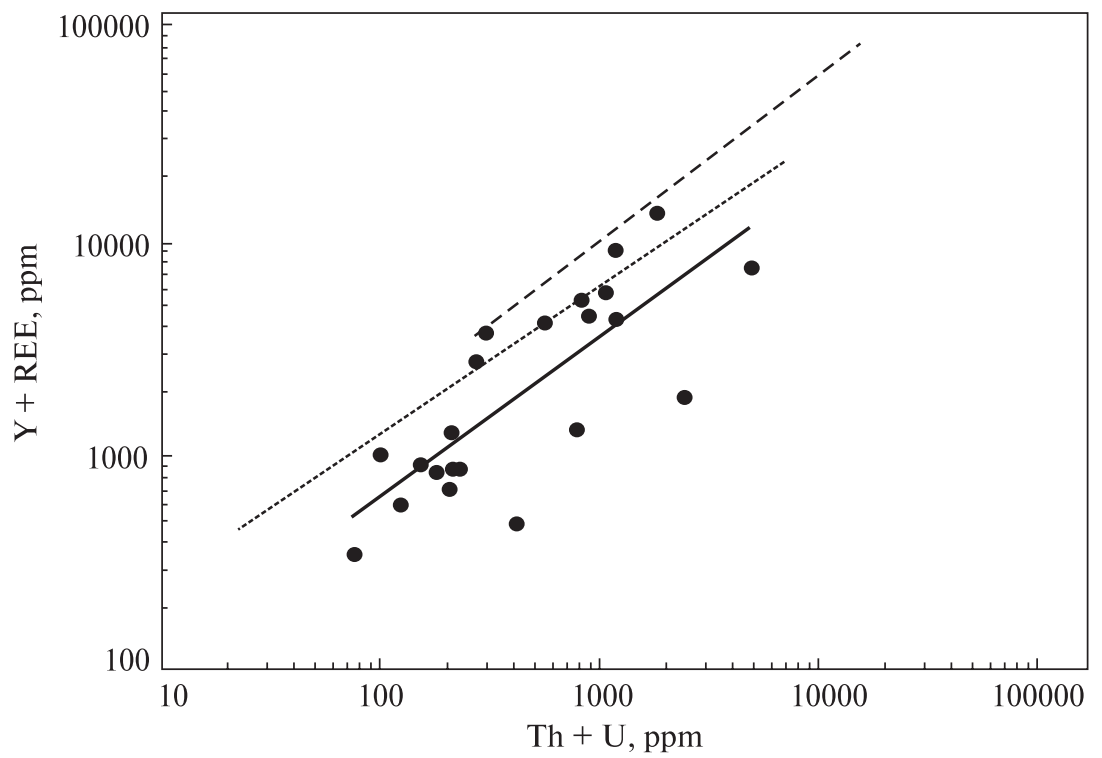

Fig. 3. Correlation of $\mathrm{Th}+\mathrm{U}$ and $R E E+\mathrm{Y}$ in zircon from the Velyka Vyska massif. The solid, dotted and broken lines show variation trends in $\mathrm{Th}+\mathrm{U}$ and $R E E+\mathrm{Y}$ concentrations in zircon from the Velyka Vyska, Azov [14, 15] and Yastrubets [15] massifs, respectively
Discussion. Zircon crystals from Velyka Vyska syenites are known to be structurally imperfect [2]. They are more similar in the degree of perfection, particularly the size of a coherent scattering zone (CHZ), to zircon from Yastrubets syenites and differ considerably from zircon in Azov syenites. The results obtained by the SIMS method do not support the assumption of radioactive radiation as the possible reason for crystal disorder. The crystals analyzed are almost identical in Th and U concentrations with zircon from Azov syenites and are much inferior to zircon from Yastrubets syenites (Fig. 3). Radioactive element concentration in zircon correlates with Y, REE and other impurities, as has been shown for other localities [2]. Considerable deviations of the figurative points of zircon composition from the trend developed are most probably provoked by the inclusions of own $R E E-$ and Th-minerals trapped by the probe.

However, the total impurity content of zircon from Velyka Vyska syenites is lower, which is not consistent with the conclusion of the effect of the total amount of impurity elements on the perfection of the crystalline lattice, as has been confirmed for zircon from the Yastrubets massif [2]. The crystals analyzed are most similar in the total amount of major impurities and their variation range to zircon from the Azov massif, as indicated by the length of corresponding trends (Fig. 3). However, substantial variations in the trace element composition of zircon from the Azov massif are caused by irregular impurity distribution between crystal parts and, to a greater extent, between crystals from the various rocks of the massif. The marginal parts of crystals from Azov melanosyenites and zircon from pegmatoid (especially leucocratic) syenites are considerably enriched in Y and REE [15]. The central parts of crystals from the ore zones of the Azov massif vary in trace and rare-earth element concentrations within one order of magnitude [14], which is much less than in crystals from the orebearing zones of the Velyka Vyska massif. Comparing isomorphic $\mathrm{Hf}$ concentrations is demonstrative. The Hf content of Azov zircon varies from 0.6 to 0.7 wt.\%, while that of Velyka Vyska zircon is $0.8-3 \mathrm{wt} . \%$. Irregular trace element distribution is typical of Velyka Vyska syenites. Samples of almost identical rocks (158/860 and 228/809 [3]) exhibit marked variations in trace element composition, ppm: $\mathrm{Zr}-2314$ and 709; REE - 328 and 927, $\mathrm{Nb}-57$ and 187, $\mathrm{Rb}-184$ and 84; $\mathrm{Sr}-9.9$ and 219 , respectively. The ${ }^{86} \mathrm{Sr} /{ }^{87} \mathrm{Sr}$ isotope ratio obtained (0.856) [9] is hard to explain genetically.

Most of zircon crystals from Azov and especially Yastrubets syenites are zonal and impurity constituents are accumulated in marginal zones, while in zircon from Velyka Vyska syenites they are distributed irregularly throughout the entire crystal. Most crystals (with few exceptions) on the BSE image are azonal with indistinct zone boundaries. It means that the redistribution of impurities and the perfecting of the crystal structure, most vigorous near crystallization temperature, were retarded in zircon from Velyka Vyska syenites. This suggests its short-term subjection to crystallization temperature provoked by the overcooling of the melt followed by the partial hardening of the mineral. As the intrusive bodies were small, favourable conditions for rapid cooling were provided. The same result could have been achieved by a rapid decline 


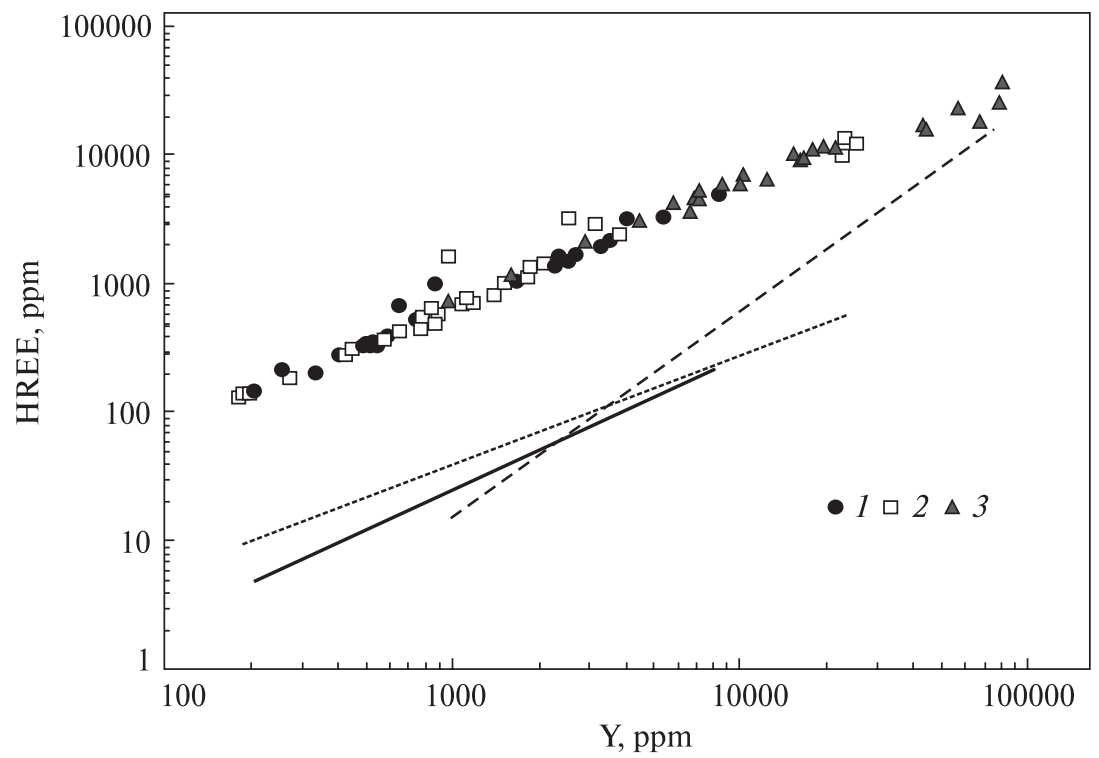

Fig. 4. Correlation of $\mathrm{Y}$ and HREE concentrations in zircon from hypersolvus syenites: 1 - Velyka Vyska massif, 2 - Azov massif, 3- Yastrubets massif. The solid, dotted and broken lines indicate variation trends in the LREE content of zircon from Velyka Vyska, Azov [14, 15] and Yastrubets [15] syenites, respectively in fluid pressure. The conclusion drawn explains the structural imperfection of zircon crystals and is consistent with earlier conclusions of the reason for the large-scale distribution of high temperature amorphous matter in Velyka Vyska syenites [1].

Yttrium is the most abundant impurity trace element. It is not surprising because $\mathrm{Y}$ is typically concentrated by zircon. Yttrium dominates over lanthanides, the $\mathrm{Y} / \mathrm{REE}$ ratio is $0.8-1.6$ (average 1.4). Almost the same mean values were obtained for zircon from Azov (0.9-2, average 1.3) and Yastrubets syenites (1-2.2, average 1.5), but the variation range of their $\mathrm{Y} / R E E$ ratio is wider. Yttrium in zircon correlates with $R E E$, as has been observed for other massifs [15], but its correlation with HREE is the closest (Fig. 4). There are some differences in the correlation of Y with $L R E E$ in zircon from various massifs (Fig. 4). LREE distributions in zircon from the Azov and Velyka Vyska massifs are almost identical ( $R E E$ composition in the Velyka Vyska massif becomes slightly heavier), while $R E E$ composition in the Yastrubets massif obviously becomes "lighter" as the total amount of trace elements in zircon increases. As maximum amounts of impurity elements are accumulated in the marginal parts of zircon, it is in these parts that REE composition becomes "lighter". Zircon from Velyka Vyska syenites is the "heaviest" in REE composition. The average $L R E E / H R E E$ ratio for this zircon is 0.06 , while those for zircon from the Azov and Yastrubets massifs are 0.18 and 0.26 , respectively. Judging by mineral parageneses, the Yastrubets massif displays the highest water and fluid saturation. The rockforming minerals of Yastrubets syenites are represented by water-bearing ferrosilicates and syngenetic carbonates. Velyka Vyska syenites are the "driest"; they are dominated by anhydrous olivine and pyroxene and contain no carbonates. Available data suggest that variations in REE composition in zircon could only be due to the fluid saturation of the crystallization medium.

Zircon crystals with indistinct zoning display identical types of spectrum in both central and marginal parts. A different type of spectra was obtained only for crystals with distinct zoning. Similar types of spectra (differentiated in the central part of a crystal and flattened in its dark marginal parts) were obtained for zircon from Azov and Yastrubets syenites. The REE distribution spectrum in the central areas of zircon shows a differentiated LREE to HREE trend, while REE distribution in dark marginal parts exhibits a flat pattern with a reduced Ce-anomaly as long as a "bird wings spectrum" appears (Fig. 2). This type of spectrum is characteristic of zircon from rocks subjected to intensive fluid effect [18]. The marginal parts of zircon crystals from the Azov and Yastrubets massifs contain high, often anomalous concentrations of $R E E, \mathrm{Y}$ and other incompatible elements (REE concentration increases to $40600 \mathrm{ppm}$ and $\mathrm{Y}$ concentration to $81500 \mathrm{ppm}$ ), which is due to the increasing saturation level of trace and $R E E$ elements in the melt triggered by the differentiation of magmatic melt at the final stage of massif formation [15]. The marginal parts of zircon from Velyka Vyska syenites typically contain low trace and rareearth element concentrations; their level in the marginal area occasionally decreases (sample 8). It seems that only the marginal parts of zircon, dark in BSE and showing flattened REE distribution 
spectra, represent zircon subjected to fluid-triggered crystallization. This conclusion is consistent with the assumption of the contribution of fluid to the "lightening" of REE composition in zircon. Other crystals were produced by crystallization of magmatic melt followed by partial hardening upon a stepwise decline in pressure or temperature or both.

Conclusions. 1. Zircon crystals from Velyka Vyska syenites crystallized from heterogenous magmatic melt enriched in rare-earth and trace elements, as indicated by various inclusions of mineral and amorphous phases.

2. Most of the zircon crystals analyzed are chemically inhomogeneous, but either azonal or show poorly-defined regular zoning. Only a few crystals have dark-grey marginal parts contrasting on a BSE image with a light grey centre.

3. Zircon from the Velyka Vyska massif contains smaller amounts of trace elements ( 0.1 to $1.6 \mathrm{wt} . \%$, average 0.4 wt. \%) than that from the Azov (average $0.7 \mathrm{wt} . \%$ ) and Yastrubets (4 wt.\%) massifs, but their distribution in a crystal is more disordered. Low concentrations of radioactive elements and other impurities could not be responsible for the structural imperfection of the crystals analyzed. Their imperfection is assumed to be due to irregular impurity distribution. Probably a stepwise decline in temperature or fluid pressure immediately after zircon crystallization resulted in relatively fast cooling and partial crystal hardening and impeded impurity segregation in the marginal parts of the crystals.

4. $R E E$ distribution spectra in zircon from Velyka Vyska syenites are of a differentiated type; they are consistent with zircon that crystallized from magma and are similar to those in the central parts of the zircon crystals from the Azov and Yastrubets massifs. Spectra of a flattened type, typical of the marginal parts of zircon characteristic of zircon crystals from these massifs, were obtained in several cases for zircon from Velyka Vyska syenites. They were revealed in marginal crystal zones with well defined zoning.

5. Zircon from the Velyka Vyska Massif and other hypersolvus massifs of the Ukrainian Shield displays a distinct correlation between yttrium and $R E E$ (especially HREE) concentrations and the predominance of the former. The average $\mathrm{Y} / R E E$ ratio varies from 1.3 to 1.5 . HREE composition in zircon is observed to slightly "lighten" with a rise in impurity concentration triggered presumably by the increased fluid saturation level of the melt.

Acknowledgements. The authors wish to thank S.G. Simakin and E.V. Potapov (Valiev IPT RAS, Yaroslavl Branch) for their assistance in zircon study. The study was conducted under IPGG RAS Research Project 0153-2019-0002.

\section{REFERENCES}

1. Gerasimets, I.M., Kulchytska, H.O. and Belskyi, V.M. (2019), Mineral. Journ. (Ukraine), Vol. 41, No. 1, Kyiv, UA, pp. 35-48 [in Ukrainian]. https://doi.org/10.15407/mineraljournal.41.01.035

2. Gerasimets, I.N., Kulchytska, H.O. and Grechanovska, O.Ye. (2018), Mineral. Journ. (Ukraine), Vol. 40, No. 2, Kyiv, UA, pp. 17-26 [in Ukrainian]. https://doi.org/10.15407/mineraljournal.40.02.017

3. Dubyna, O.V. and Kryvdik, S.G. (2013), Mineral. Journ. (Ukraine), Vol. 35, No. 3, Kyiv, UA, pp. 61-72 [in Ukrainian].

4. Kvasnytsya, V.M., Vyshnevskyi, O.A., Kvasnytsya, I.V. and Gurnenko, I.O. (2016), Mineral. Journ. (Ukraine), Vol. 38, No. 3, Kyiv, UA, pp. 9-23 [in Ukrainian]. https://doi.org/10.15407/mineraljournal.38.03.009

5. Kryvdik, S.G. and Tkachuk, V.I. (1990), Petrologiya shchelochnyh porod Ukrainskogo shchita, Nauk. dumka, Kyiv, UA, 408 p. [in Russian].

6. Kryvdik, S.G. (2002), Geochemistry, No. 7, Moscow, RU, pp. 707-716 [in Russian].

7. Kryvdik, S.G. (2005), Mineral. Journ. (Ukraine), Vol. 27, No. 3, Kyiv, UA, pp. 41-49 [in Ukrainian].

8. Kryvdik, S.G. and Bezsmolova, N.V. (2011), Geol. Journ., No. 3, Kyiv, UA, pp. 39-45 [in Ukrainian].

9. Kryvdik, S.G., Dubyna, O.V., Dovbush, T.I., Kotvytska, I.M., Vysotsky, O.B., Bezsmolova, N.V. and Amashukeli, Yu.A. (2011), Mineral. Journ. (Ukraine), Vol. 33, No. 3, Kyiv, UA, pp. 55-62 [in Ukrainian].

10. Kryvdik, S.G., Zagnitko, V.M., Strekozov, S.M., Hurskyy, D.S., Vasil'chenko, V.V. and Matviychuk, M.V. (2000), Mineral. Journ. (Ukraine), Vol. 22, No. 1, Kyiv, UA, pp. 62-72 [in Ukrainian].

11. Krochuk, V.M., Legkova, G.V., Galaburda, Yu.A., Orsa, V.I. and Usova, L.V. (1989), Mineral. Journ. (Ukraine), Vol. 11, No. 5, Kyiv, UA, pp. 18-29 [in Russian].

12. Kulchytska, H.O., Gerasimets, I.N., Vyshnevskyi O.A. and Belskyi, V.M. (2019), Mineral. Journ. (Ukraine), Vol. 41, No. 2, Kyiv, UA, pp. 34-44 [in Ukrainian]. https://doi.org/10.15407/mineraljournal.41.02.034

13. Kulchytska, H.O., Chernysh, D.S. and Herasymets, I.M. (2020), Mineral. Journ. (Ukraine), Vol. 42, No. 1, Kyiv, UA, pp. 36-48 [in Ukrainian]. https://doi.org/10.15407/mineraljournal.42.01.036

14. Levashova, E.V., Voznyak, D.K., Skublov, S.G., Kaulina, T.V., Kulchytska, H.O. and Galankina, O.L. (2019), Mineral. Journ. (Ukraine), Vol. 41, No. 2, Kyiv, UA, pp. 45-61 [in Russian]. https://doi.org/10.15407/mineraljournal.41.02.045 
15. Levashova, E.V., Skublov, S.G., Li, X.H., Kryvdik, S.G., Voznyak, D.K., Kulchytska, H.O. and Alekseev, V.I. (2016), Geol. Ore Deposits, Vol. 58, pp. 239-362. https://doi.org/10.1134/S1075701516030065

16. Melnikov, V.S., Kulchytska, H.O., Kryvdik, S.G. and Strekozov S.M. (2001), Mineral. Journ. (Ukraine), Vol. 23, No. 4, Kyiv, UA, pp. 19-33 [in Ukrainian].

17. Melnikov, V.S., Voznyak, D.K., Grechanovskaya, E.E., Gursky, D.S., Kulchytska, H.O. and Strekozov, S.N. (2000), Mineral. Journ. (Ukraine), Vol. 22, No. 1, Kyiv, UA, pp. 42-61 [in Russian].

18. Skublov, S.G. (2005), Geohimiya redkozemelnyih elementov v porodoobrazuyuschih metamorficheskih mineralah, Nauka, St. Petersburg, RU, 147 p. [in Russian].

19. Fedotova, A.A., Bibikova, E.V. and Simakin, S.G. (2008), Geochem. Intern., Vol. 46, No. 9, RU, pp. 912-927. https:// doi.org/10.1134/S001670290809005X

20. Harley, S.L. and Kelly, N.M. (2007), Elements, Vol. 3, No. 1, pp. 13-18. https://doi.org/10.2113/gselements.3.1.13

21. Hinton, R.W. and Upton, B.G.J. (1991), Geochim. et Cosmochim. Acta., Vol. 55, Iss. 11, pp. 3287-3302. https://doi. org/10.1016/0016-7037(91)90489-R

22. Hoskin, P.W.O. and Schaltegger, U. (2003), Review Mineral. and Geochem., Vol. 53, No. 1, pp. 27-62. https://doi. org/10.2113/0530027

23. McDonough, W.F. and Sun, S.-S. (1995), Chem. Geol., Vol. 120, Iss. 3-4, pp. 223-253. https://doi.org/10.1016/00092541(94)00140-4

24. Watson, E.B, Wark, D.A. and Thomas, J.B. (2006), Contribs. Mineral. and Petrol., Vol. 151, pp. 413-433. https://doi. org/10.1007/s00410-006-0068-5

Received 08.06.2020

К.В. Лєвашова, канд. геол.-мін. наук, мол. наук. співроб. Інститут геології та геохронології докембрію РАН 199034, м. Санкт-Петербург, РФ, наб. Макарова, 2

E-mail: levashova.kateryna@yandex.ru; https://orcid.org/0000-0002-0814-1428

Г.О. Кульчицька, д-р геол. наук, гол. наук. співроб.

Інститут геохімії, мінералогії та рудоутворення (ІГМР) ім. М.П. Семененка НАН України

03142, м. Київ, Україна, пр-т Акад. Палладіна, 34

E-mail: kulchechanna@gmail.com; https://orcid.org/0000-0002-7206-4797

С.Г. Скублов, д-р геол.-мін. наук, проф., гол. наук. співроб. Інститут геології та геохронології докембрію РАН 199034, м. Санкт-Петербург, РФ, наб. Макарова, 2

Санкт-Петербурзький гірничий університет

199106, м. Санкт-Петербург, РФ, ВО, 21 лінія, 2

E-mail: skublov@yandex.ru; Scopus ID: 55918967400

I.M. Герасимець, канд. геол. наук, мол. наук. співроб. ІГМР ім. М.П. Семененка НАН України

03142, м. Київ, Україна, пр-т Акад. Палладіна, 34

E-mail: Herasimets@i.ua; https://orcid.org/0000-0003-4670-0216

С.Г. Кривдік, д-р геол.-мін. наук, проф., гол. наук. співроб. ІГМР ім. М.П. Семененка НАН України

03142, м. Київ, Україна, пр-т Акад. Палладіна, 34

E-mail: kryvdik@ukr.net; http://orcid.org/0000-0002-8356-1115

О.Л. Галанкіна, канд. геол.-мін. наук, старш. наук. співроб. Інститут геології та геохронології докембрію РАН 199034, м. Санкт-Петербург, РФ, наб. Макарова, 2

E-mail: galankinaol@mail.ru; Scopus ID: 7801578217

M.Є. Мамикіна, студент. Санкт-Петербурзький гірничий університет

199106, м. Санкт-Петербург, РФ, ВО, 21 лінія, 2

E-mail: emamikina@mail.ru

Д.С. Лєвашов, канд. техн. наук, доцент. Санкт-Петербурзький гірничий університет

199106, м. Санкт-Петербург, РФ, ВО, 21 лінія, 2

E-mail: levashov_ds@pers.spmi.ru; ResearcherID: AAI-1742-2019

\section{ГЕОХІМІЯ РІДКІСНИХ ЕЛЕМЕНТІВ У ЦИРКОНІ 3 СІЕНІТІВ ВЕЛИКОВИСКІВСЬКОГО МАСИВУ, УКРАЇНСЬКИЙ ЩИТ}

Досліджено кристали циркону із протолочок сієнітів розрізнених інтрузивних тіл Великовисківського масиву методами SEM-EDS і SIMS. Отримані результати зіставлені з опублікованими раніше даними для циркону із сієнітових масивів Українського щита з $\mathrm{Zr}-R E E$ мінералізацією - Азовського і Яструбецького. На $B S E$-зображенні кристали азональні або зі слабко виявленою зональністю. Лише в поодиноких індивідах проявлена контрастно темніша крайова зона. Виявлені в кристалах силікатні, сульфідні, фосфатні і карбонатні тверді фази підтвердили гетерогенізацію середовища кристалізації циркону. Вміст рідкісних, у тому числі рідкісноземельних і радіоактивних, елементів не перевищує 1,6 мас. \% за середнього значення 0,4 мас. \%, що менше, ніж у цирконах із інших масивів. Вміст U + Th (середнє значення 0,07 мас. \%) не дає змоги розглядати радіоактивні елементи як джерело руйнування структури кристалів. Подібно до циркону з інших масивів, провідна роль серед елементів-домішок 
належить ітрію, який переважає над $R E E$ зі співвідношенням 1,3 : 1. Спостерігається деяке "полегшення" складу $R E E$ зі збільшенням загального вмісту Y і REE. "Найважчим" є циркон з великовисківських сієнітів. Середнє відношення LREE/HREE для цього циркону - 0,06, тоді як для цирконів з Азовського і Яструбецького масивів - 0,18 і 0,26 відповідно. Спектри розподілу $R E E$ у цирконі представлені двома типами. Перші - диференційовані, властиві більшості кристалів. Вони ідентичні спектрам центральних зон кристалів 3 інших масивів і характерні для циркону, що кристалізувався з розплаву. Другі - пологі, властиві крайовим ділянкам кристалів 3 чітко вираженою зональною будовою. Вони ідентичні спектрам для крайових зон кристалів циркону з інших масивів і характерні для циркону, кристалізація якого мала місце за участі флюїдної фази. Розрахована за Ті-термометром температура кристалізації циркону коливається у межах $600-1000{ }^{\circ} \mathrm{C}$, більшість значень відповідає $700-800{ }^{\circ} \mathrm{C}$, що дещо менше, ніж очікувалося.

Ключові слова: циркон, сієніт, Великовисківський масив, ітрій, радіоактивні та рідкісноземельні елементи, REEродовище. 